\title{
Optimization of Water Circulation Period for the Culture of Goldfish with Spinach in Aquaponic System
}

\author{
A. P. Shete ${ }^{1}$, A. K. Verma ${ }^{1}$, R. S. Tandel ${ }^{1}$, Chandra Prakash $^{1}$, V. K. Tiwari ${ }^{1} \&$ Tanveer Hussain $^{1}$ \\ ${ }^{1}$ Department of Aquaculture, Central Institute of Fisheries Education, Yari Road, Versova, Andheri (W), Mumbai, \\ India \\ Correspondence: A. K. Verma, Department of Aquaculture, Central Institute of Fisheries Education, Yari Road, \\ Versova, Andheri (W), Mumbai, India. Tel: 91-2226-310-657. E-mail: akverma45@yahoo.com
}

Received: December 17, 2012 Accepted: February 20, 2013 Online Published: March 15, 2013

doi:10.5539/jas.v5n4p26

URL: http://dx.doi.org/10.5539/jas.v5n4p26

\begin{abstract}
Experiment with varied water circulation periods having 4, 8, 12, and $24 \mathrm{hrs} / \mathrm{day}$ as T1, T2, T3 and T4, respectively in aquaponics, evaluated against a control (without aquaponics) revealed higher fish and plant growth in T3 and T4. The mean growth of fish varied significantly among treatments showing higher growth in T4 and control followed by T3, T2 and T1. Survival rate was $100 \%$ in all the treatments as well as control. Percentage weight gain, SGR $\left(\% \mathrm{day}^{-1}\right)$ also showed the similar trend as that of growth showing T4 as better treatment immediately followed by $\mathrm{T} 3$ then $\mathrm{T} 2$ and $\mathrm{T} 1$. The system maintained favourable water quality throughout the experiment. The growth in T3 and T4 did not vary significantly and was higher than the T1, T2 and control. Also percentage length gain at the end of the trial was maximum in T3 and T4. The $\mathrm{Chl}(\mathrm{a}+\mathrm{b})$ content in the control was higher than all the treatments whereas, $\mathrm{T} 4$ showed the maximum concentration among treatments followed by T3, T2 and then T1. Comparison of all the growth attributes and water quality parameters indicated that water circulation can be reduced to $12 \mathrm{hrs} /$ day for economically effective aquaponics and can be considered as optimum water circulation period for goldfish production in aquaponic system.
\end{abstract}

Keywords: aquaponics, hydroponics, goldfish, spinach

\section{Introduction}

Aquarium fishes are rapidly gaining importance not only because of their aesthetic value but also due to their immense commercial value in the export trade all over the world. Among ornamental fishes, goldfish, Carassius auratus (Linnaeus, 1758) of the Cyprinidae family remained popular. Due to ever growing demand of goldfish, there is an urgent need to intensify its culture. Thus, high intensification of goldfish culture necessitates high water exchange, which also leads to pollution of the water bodies due to effluent discharge. Moreover, goldfish culture system requires a constant water supply which is generally not available in most of the places and especially in water scarce areas (Mozes et al., 2003). The introduction of a recirculating aquaculture system (RAS) for intensive culture of goldfish can solve the above mentioned problems. Mostly recirculating systems are designed to replace $5-10 \%$ of the system volume daily with new water to prevent the buildup of nitrate-nitrogen concentration in the culture tank (Masser et al, 1999). Aquaponic systems are recirculating aquaculture systems that incorporate the production of plants without soil. Aquaponic systems require substantially less water quality monitoring than separate hydroponic or recirculating aquaculture systems. Vegetables are candidate plants for use in recirculating hydroponic systems as they grow rapidly in response to the high levels of nutrients in aquaculture water. Different species of vegetables such as ice-lettuce, tomatoes, leaf lettuce, and basil have been successfully grown in aquaculture wastewater (Naegel, 1977; Quillere et al., 1995; McMurtry et al., 1997; Rakocy et al., 2006). Now, there is a strong need for establishing a technology which allows for the efficient cultivation of these food groups while conserving freshwater and land resources. This study was aimed at optimizing the water circulation period suitable for aquaponic system.

\section{Material and Methods}

The experiment was conducted at wet lab of Department of Aquaculture, Central Institute of Fisheries Education, Mumbai, India. It consisted of four treatments, each having three randomly assigned replications. Different water circulation hours i.e. $4 \mathrm{hrs} /$ day, $8 \mathrm{hrs} /$ day, $12 \mathrm{hrs} /$ day and $24 \mathrm{hrs} /$ day were assigned as four treatments, T1, T2, T3 and T4, respectively. Regular water exchange was followed in Control set in glass aquaria with three 
replicates. 12 rectangular fiberglass tank of $40 \mathrm{~L}$ capacity were selected for fishes and 12 round plastic tubs of 75 L capacity were selected for plantation. 3 glass aquaria each of $20 \mathrm{~L}$ capacity were selected as control for fish and control plants were planted in small plot $\left(0.05 \mathrm{~m}^{-2}\right)$ of field of the campus. Seed of spinach (Spinacea oleracea) was procured from the nursery allowed to grow for 15 days before transplanting into the experimental setup aquaponics.

Fry of Goldfish were stocked in each tank at 500 no. $\mathrm{m}^{-3}$ stocking density. The mean stocking size of fry was recorded by taking measurements of all fishes before stocking. The stocking size was $3.8 \pm 0.003 \mathrm{~cm}$ and $1.5 \pm$ $0.008 \mathrm{gm}$. Plants were transplanted from garden to experimental tubs at a stocking density of 28 plants per square meter. The stocking size of plants was $6.9 \pm 0.117 \mathrm{~cm}$. The fry were provided with artificial pelleted feed containing $35.01 \%$ protein, $8.31 \%$ lipid, $3.72 \%$ fibre, $10.12 \%$ ash at $5 \%$ of body weight twice a day $(10.00$ and $17.00 \mathrm{Hrs}$ ). All round tubs were filled with gravel upto the height of $15 \mathrm{~cm}$ and the water was circulated from the fish culture tank with air-lift pumps. Fishes and plants were sampled every 15 days to measure various growth parameters.

Water quality parameters viz., temperature, $\mathrm{pH}$, dissolved oxygen, free carbon dioxide, total hardness, alkalinity, ammonia, nitrite and nitrate were recorded during the experimental period with an interval of 7 days using the standard methods outlined in APHA (2005). Chlorophyll content of spinach was estimated according to method followed by Knudson et al. (1977) at the start and end of the experiment.

The data were subjected to analysis using statistical package SPSS version 16 in which one way ANOVA and Duncan's Multiple Range Test were performed at a significance level of $(\mathrm{P}<0.05)$ at $95 \%$ confidence limit to know the significant difference between the treatment means for different parameters.

\section{Results and Discussion}

Recirculating aquaculture systems provide the benefit of low water consumption and high fish production but it also involves economic investment as electricity is consumed by pumps for water circulation. Advantage of aquaponic system cuts down this cost to some level by production of secondary crop of vegetables and improves a system's profit potential. The plants remove nutrients from the culture water and eliminate the need for separate and expensive biofilters (Rakocy et al., 2006). The $\mathrm{pH}$, temperature, dissolved oxygen, free $\mathrm{CO}_{2}$ were maintained within the favourable ranges (Table 1) by the aquaponic system. Total alkalinity did not show any significant difference among all treatments but in control it was at lower levels. Total hardness was significantly higher in T4 than the other treatments (T1 to T3) and control. Different water circulation period affected TAN and Nitrite-N levels, which are toxic to the fish growth. TAN levels varied significantly and showed higher concentrations in control when compared with treatments. There was no significant difference among treatments but values showed decreasing trend with increasing water circulation periods. Nitrite- $\mathrm{N}$ concentration also did not show any significant variation but showed slight reduction with increase of water circulation. Lennard and Leonard (2004) in their comparative studies of reciprocating flow versus constant flow in an integrated-gravel bed-aquaponics system showed that constant flow treatment appear to remove more nitrate from culture waters than did reciprocating control treatments, but no significant differences was detected. Nitrate- $\mathrm{N}$ concentration of water, which is relatively harmless to fishes, was also found to be in the favourable range in all treatments. When the values of Nitrogen compounds of all the treatments were compared with control, values of control and treatments shown similarity and were within the acceptable limits. Thus, it can be concluded that, without water exchange aquaponic system maintains the water quality suitable for fish culture which is usually maintained by daily $20-30 \%$ water exchange in tank culture systems.

The mean growth of fish varied significantly among treatments showing higher growth in $\mathrm{T} 4$ and control followed by T3, T2 and T1 (Table 2). Zarski et al. (2010) also conducted similar study to compare closed and semi-closed recirculatory system during intensive culture of goldfish. Goldfishes were stocked at $500 \mathrm{~m}^{-3}$ density. Semi-closed recirculating aquaculture system with $20 \%$ daily water replacement showed the better results. This also indicates that the growth of goldfish was better in the systems with better water quality. Survival rate was $100 \%$ in all the treatments as well as control. Percentage weight gain, SGR $\left(\%\right.$ day $\left.^{-1}\right)$ also showed the similar trend as that of growth showing T4 as better treatment immediately followed by T3 then T2 and T1. 
Table 1 . Water quality parameters observed during experiment

\begin{tabular}{llllll}
\hline Parameters & Control & $\mathrm{T} 1$ & $\mathrm{~T} 2$ & $\mathrm{~T} 3$ & $\mathrm{~T} 4$ \\
\hline Temperature $\left({ }^{\circ} \mathrm{C}\right)$ & $27.05 \pm 0.327^{\mathrm{a}}$ & $27.72 \pm 0.364^{\mathrm{a}}$ & $27.5 \pm 0.311^{\mathrm{a}}$ & $27.44 \pm 0.269^{\mathrm{a}}$ & $27.77 \pm 0.301^{\mathrm{a}}$ \\
$\mathrm{pH}$ & $7.4 \pm 0.100^{\mathrm{a}}$ & $7.6 \pm 0.117^{\mathrm{a}}$ & $7.5 \pm 0.083^{\mathrm{a}}$ & $7.5 \pm 0.083^{\mathrm{a}}$ & $7.6 \pm 0.138^{\mathrm{a}}$ \\
$\mathrm{DO}\left(\mathrm{mg} \mathrm{L}^{-1}\right)$ & $5.4 \pm 0.052^{\mathrm{a}}$ & $5.2 \pm 0.080^{\mathrm{a}}$ & $5.4 \pm 0.077^{\mathrm{a}}$ & $5.4 \pm 0.092^{\mathrm{a}}$ & $5.4 \pm 0.081^{\mathrm{a}}$ \\
Free CO2 $\left(\mathrm{mg} \mathrm{L}^{-1}\right)$ & $3.5 \pm 0.153^{\mathrm{a}}$ & $3.9 \pm 0.144^{\mathrm{ab}}$ & $4.0 \pm 0.145^{\mathrm{b}}$ & $3.5 \pm 0.120^{\mathrm{a}}$ & $3.5 \pm 0.122^{\mathrm{a}}$ \\
Alkalinity $\left(\mathrm{mg} \mathrm{L}^{-1}\right)$ & $55.8 \pm 2.263^{\mathrm{a}}$ & $80.2 \pm 4.182^{\mathrm{b}}$ & $80.4 \pm 4.038^{\mathrm{b}}$ & $81.8 \pm 4.423^{\mathrm{b}}$ & $76.0 \pm 4.481^{\mathrm{b}}$ \\
Hardness $\left(\mathrm{mg} \mathrm{L}^{-1}\right)$ & $60.7 \pm 1.372^{\mathrm{a}}$ & $63.7 \pm 1.714^{\mathrm{a}}$ & $64 \pm 2.309^{\mathrm{a}}$ & $67.7 \pm 2.413^{\mathrm{ab}}$ & $72.2 \pm 3.307^{\mathrm{b}}$ \\
Ammonia $\left(\mathrm{mg} \mathrm{L}^{-1}\right)$ & $0.47 \pm 0.081^{\mathrm{b}}$ & $0.30 \pm 0.028^{\mathrm{a}}$ & $0.25 \pm 0.02^{\mathrm{a}}$ & $0.23 \pm 0.013^{\mathrm{a}}$ & $0.22 \pm 0.015^{\mathrm{a}}$ \\
Nitrite-N $\left(\mathrm{mg} \mathrm{L}^{-1}\right)$ & $0.04 \pm 0.011^{\mathrm{a}}$ & $0.04 \pm 0.007^{\mathrm{a}}$ & $0.04 \pm 0.003^{\mathrm{a}}$ & $0.03 \pm 0.004^{\mathrm{a}}$ & $0.02 \pm 0.003^{\mathrm{a}}$ \\
Nitrate-N $\left(\mathrm{mg} \mathrm{L}^{-1}\right)$ & $0.23 \pm 0.024^{\mathrm{a}}$ & $0.26 \pm 0.023^{\mathrm{a}}$ & $0.25 \pm 0.016^{\mathrm{a}}$ & $0.28 \pm 0.016^{\mathrm{a}}$ & $0.28 \pm 0.021^{\mathrm{a}}$ \\
\hline
\end{tabular}

Table 2. Fish growth parameters observed during experiment

\begin{tabular}{llllll}
\hline Parameter & Control & T1 & T2 & T3 & T4 \\
\hline a) Stocking & & & & & \\
Water circulation period (hrs) & - & 4 & 8 & 12 & 24 \\
Mean weight $(\mathrm{gm} \pm \mathrm{SE})$ & $1.56 \pm 0.014^{\mathrm{b}}$ & $1.55 \pm 0.018^{\mathrm{b}}$ & $1.50 \pm 0.008^{\mathrm{a}}$ & $1.49 \pm 0.003^{\mathrm{a}}$ & $1.50 \pm 0.005^{\mathrm{a}}$ \\
$\begin{array}{l}\text { Mean Length }(\mathrm{cm} \pm \mathrm{SE}) \\
\text { b) Harvest }\end{array}$ & $3.80 \pm 0.003^{\mathrm{a}}$ & $3.81 \pm 0.005^{\mathrm{a}}$ & $3.78 \pm 0.003^{\mathrm{a}}$ & $3.80 \pm 0.003^{\mathrm{a}}$ & $3.80 \pm 0.012^{\mathrm{a}}$ \\
Culture period (days) & 60 & & & & \\
Weight $(\mathrm{gm} \pm \mathrm{SE})$ & $3.52 \pm 0.012^{\mathrm{c}}$ & $3.40 \pm 0.008^{\mathrm{a}}$ & $3.48 \pm 0.005^{\mathrm{a}}$ & $3.51 \pm 0.005^{\mathrm{b}}$ & $3.56 \pm 0.014^{\mathrm{c}}$ \\
Length $(\mathrm{cm} \pm \mathrm{SE})$ & $5.43 \pm 0.006^{\mathrm{cd}}$ & $5.32 \pm 0.015^{\mathrm{a}}$ & $5.38 \pm 0.012^{\mathrm{b}}$ & $5.40 \pm 0.003^{\mathrm{bc}}$ & $5.43 \pm 0.008^{\mathrm{d}}$ \\
Survival $(\%)$ & 100 & 100 & 100 & 100 & 100 \\
c) Gain & & & & & \\
SGR & $1.35 \pm 0.020^{\mathrm{b}}$ & $1.30 \pm 0.017^{\mathrm{a}}$ & $1.39 \pm 0.011^{\mathrm{bc}}$ & $1.42 \pm 0.006^{\mathrm{cd}}$ & $1.44 \pm 0.005^{\mathrm{d}}$ \\
FCR & $4.88 \pm 0.080^{\mathrm{b}}$ & $4.85 \pm 0.043^{\mathrm{b}}$ & $4.62 \pm 0.038^{\mathrm{a}}$ & $4.54 \pm 0.063^{\mathrm{a}}$ & $4.62 \pm 0.010^{\mathrm{a}}$ \\
\hline
\end{tabular}

Different water circulation periods had shown positive effect on the plant growth (Table 3) as it was important factor for nutrients exposure to plants. The growth in T3 and T4 did not vary significantly and was higher than the T1, T2 and control. Also percentage length gain at the end of the trial was maximum in T3 and T4. These results indicate that, maximum growth was obtained in 12 and $24 \mathrm{hrs} /$ day circulation periods because plants were exposed to nutrients for more time. The study conducted by Trang et al. (2010) showed that the water spinach, Ipomea aquatica, grown best in the flooded hydroponic sub-system which allows maximum surface area and time for nutrient utilization to plants. This result also supports the values of TAN and Nitrite- $\mathrm{N}$ in these treatments. As plants used more nutrients, the values of Tan and Nitrite-N were lower.

Leaf chlorophyll content provides valuable information about the physiological status of plants (Gitelson et al., 2008). Chlorophyll gives an indirect estimation of the nutrient status because much of the leaf nitrogen is incorporated in Chlorophyll (Filella et al., 1995). Chlorophyll content of plant is also an indicator of the health status of plant. It was also affected by water circulation periods. The levels of $\mathrm{Chl}(\mathrm{a}+\mathrm{b})$ in the leave shown increasing trend with the increase in water circulation periods. The $\mathrm{Chl}(\mathrm{a}+\mathrm{b})$ content in the control was higher than all the treatments whereas, T4 showed the maximum concentration among treatments followed by T3, T2 and then $\mathrm{T} 1$.

The lower levels of TAN and Nitrite-N might have caused higher growth of fishes in T3 and T4. It may be due to the increased water circulation period which allows plants to strip more nutrients from the water. From the overall results, it can be concluded that the water circulation period can be reduced from $24 \mathrm{hrs} /$ day to $12 \mathrm{hrs} / \mathrm{day}$ 
to make the aquaponic system economically efficient which gives better yields of fish as well as plants and minimizes the electricity consumption.

Table 3. Plant growth parameters observed during experiment

\begin{tabular}{llllll}
\hline Parameter & Control & T1 & T2 & T3 & T4 \\
\hline $\begin{array}{l}\text { a) Stocking } \\
\text { Mean Length }(\mathrm{cm} \pm \mathrm{SE})\end{array}$ & $7.10 \pm 0.404^{\mathrm{a}}$ & $6.9 \pm 0.115^{\mathrm{a}}$ & $7.03 \pm 0.484^{\mathrm{a}}$ & $6.80 \pm 0.577^{\mathrm{a}}$ & $6.80 \pm 0.173^{\mathrm{a}}$ \\
b) Harvest & & & & \\
Culture Period (days) & 60 & 60 & 60 & 60 & 60 \\
Mean Length $(\mathrm{cm} \pm \mathrm{SE})$ & $21.06 \pm 0.296^{\mathrm{b}}$ & $19.03 \pm 0.290^{\mathrm{a}}$ & $20.50 \pm 0.285^{\mathrm{b}}$ & $23.52 \pm 0.289^{\mathrm{c}}$ & $24.06 \pm 0.120^{\mathrm{c}}$ \\
Chlorophyll $(\mathrm{a}+\mathrm{b})$ & $81.09 \pm 0.165^{\mathrm{e}}$ & $49.53 \pm 0.381^{\mathrm{a}}$ & $69.48 \pm 0.706^{\mathrm{b}}$ & $73.27 \pm 0.615^{\mathrm{c}}$ & $76.28 \pm 1.228^{\mathrm{d}}$ \\
\hline
\end{tabular}

Mean values with same superscript did not show any significant difference $(\mathrm{P}>0.05)$.

\section{Conclusion}

Development of the optimum conditions, e.g., fish species fish to plant ratio, plant species, stocking density and water circulation time, for system design and operation in aquaponics is vital in order to maximize fish and plant productions and minimize water exchange and nutrient accumulation as well as beneficial environmental impacts. This study demonstrated that the change in the water circulation period has effect on the water quality, fish growth as well as plant growth. The optimal water circulation period in terms of fish production, plant growth and water quality was found to be $12 \mathrm{hr} /$ day.

\section{References}

APHA. (2005). Standards Methods for the examination of Water and Waste water (21th ed.). Washington D. C. Retrieved from http://www.worldcat.org/title/standard-methods-for-the-examination-of-water-and-wastewater/oclc/156744 115

Filella, I., Serrano, I., Serra, J., \& Penuelas, J. (1995). Evaluating wheat nitrogen status with canopy reflectance

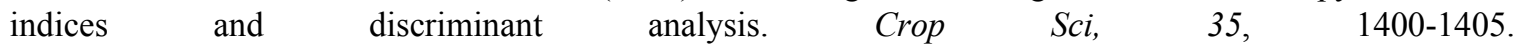
http://dx.doi.org/10.2135/cropsci1995.0011183X003500050023x

Gitelson, A. A., Steele, M., \& Rundquist, D. (2008). Nondestructive Estimation of Leaf Chlorophyll Content in Grapes. American Journal of Enology and Viticulture, 59(3), 299-305. http://digitalcommons.unl.edu/cgi/viewcontent.cgi?article $=1284 \&$ context=natrespapers

Knudson, L. L., Tibbitts, T. W., \& Edwards, G. E. (1977). Measurement of Ozone Injury by Determination of Leaf Chlorophyll concentration. Plant Physiol, 60, 606-608. http://dx.doi.org/10.1104/pp.60.4.606

Lennard, W. A., \& Leonard, B. V. (2004). A comparison of reciprocal flow versus constant flow in an integrated, gravel bed, aquaponic test system. Aquacult. Int., 12, 539-553. http://dx.doi.org/10.1007/s10499-004-8528-2

Masser, M. P., Rakocy, J., \& Losordo, T. M. (1999). Recirculating aquaculture tank production systems-Management of recirculating systems. SRAC Publication, No. 452 USDA (p. 12). Retrieved from https://srac.tamu.edu/index.cfm/event/getFactSheet/whichfactsheet/103/

McMurtry, M. R., Sanders, D. C., Cure, J. D., Hodson, R. G., Haning, B. C., \& St. Amand, P. C. (1997). Efficiency of water use of an integrated fish/vegetable co-culture system. J. World Aquacult. Soc., 28, 420-428. http://dx.doi.org/10.1111/j.1749-7345.1997.tb00290.x

Mozes, N., Eshchar, M., Conijeski, D., Fediuk, M., \& Ashkenazy, A. (2003). Marine Recirculating Systems in Israel - Performance, Production Cost Analysis And Rationale For Desert Conditions. The Israeli Journal of Aquaculture - $\quad$ Bamidgeh, 55(4), 274-282. Retrieved from http://evols.library.manoa.hawaii.edu/bitstream/handle/10524/19091/55_4_Mozes.pdf?sequence=1

Naegel, L. C. A. (1977). Combined production of fish and plants in recirculating water. Aquaculture, 10, 17-24. http://dx.doi.org/10.1016/0044-8486(77)90029-1 
Quillere, I., Roux, L., Marie, D., Roux, Y., Gosse, F., \& Morotgaudry, J. F. (1995). An artificial productive ecosystem based on a fish bacteria plantassociation. 2. Performance. Agric. Ecosyst. Environ., 53, 19-30. http://dx.doi.org/10.1016/0167-8809(94)00551-O

Rakocy, J. E., Masser, M. P., \& Losordo, T. M. (2006). Recirculating Aquaculture Tank Production Systems: Aquaponics-Integrating Fish and Plant Culture. SRAC Publication, No. 454 USDA. Retrieved from https:/srac.tamu.edu/index.cfm/event/getFactSheet/whichfactsheet/105/

Trang, N. T. D., Schierup, H., \& Brix, H. (2010). Leaf vegetables for use in integrated hydroponics and aquaculture systems: Effects of root flooding on growth, mineral composition and nutrient uptake. African $\begin{array}{llll}\text { Journal of } & \text { Biotechnology, } & \text { 4186-4196. }\end{array}$ http://www.academicjournals.org/AJb/abstracts/abs2010/5Jul/Trang\%20et\%20al.htm

Zarski, D., Kucharczyk, D., Targonska, K., Krejszeff, S., Czarkowski, T., Babiarz, E., \& Nowosielska, D. B. (2010). Dynamics of nitrogen and phosphorus in closed and semi-closed recirculating aquaculture systems during the intensive culture of goldfish, Carassius auratus auratus (L.), juveniles. Arch. Pol. Fish, 18, 187-193. $\quad$ Retrieved from http:/www.infish.com.pl/wydawnictwo/Archives/Fasc/work_pdf/Vol18Fasc3/Vol18-Fasc3-\%20w08.pdf 